\title{
MicroRNAs in ovarian carcinomas
}

\author{
Neetu Dahiya ${ }^{1}$ and Patrice J Morin ${ }^{1,2}$
}

${ }^{1}$ Laboratory of Cellular and Molecular Biology, National Institute on Aging, NIH Biomedical Research Center, 251 Bayview Boulevard, Suite 100, Room 6C228, Baltimore, Maryland 21224, USA

${ }^{2}$ Department of Pathology, Johns Hopkins Medical Institutions, Baltimore, Maryland 21287, USA

(Correspondence should be addressed to P J Morin at Laboratory of Cellular and Molecular Biology, National Institute on Aging, NIH Biomedical Research Center; Email: morinp@mail.nih.gov)

\begin{abstract}
The molecular mechanisms involved in epithelial ovarian cancer initiation and progression are just beginning to be elucidated. In particular, it has become evident that microRNAs (miRNAs or miRs), a class of molecules that post-transcriptionally regulate gene expression, play a major role in ovarian tumorigenesis. Several microRNA profiling studies have identified changes in microRNA patterns that take place during ovarian cancer development. While most deregulated microRNAs are down-regulated in cancer, and may therefore act as tumor suppressors, others are elevated and may represent novel oncogenes in this disease. A number of microRNAs identified as aberrantly expressed in ovarian carcinoma have been shown to have important functional roles in cancer development and may therefore represent targets for therapy. In addition, some of the microRNA patterns may have prognostic significance. The identification of functional targets represents a major hurdle in our understanding of microRNA function in ovarian carcinoma, but significant progress is being made. It is hoped that a better understanding of the microRNA expression and roles in ovarian cancer may provide new avenues for the detection, diagnosis, and therapy of this deadly disease.
\end{abstract}

Endocrine-Related Cancer (2010) 17 F77-F89

\section{Introduction}

Ovarian cancer is the sixth most common gynecologic malignancy in women worldwide (over 230000 new cases yearly) with a highly aggressive natural history and causing over 140000 deaths every year (Garcia et al. 2007). While the survival rates of women with early stage ovarian cancer are high, most cases are diagnosed late, when the likelihood of successful therapy is low (Piver et al. 1992, Ahmed et al. 1996, Wright et al. 2009). Indeed, cytotoxic chemotherapy for ovarian carcinoma is often unsuccessful due to common resistance to the current chemotherapeutic regimens (Fung-Kee-Fung et al. 2007). MicroRNAs (miRNAs or miRs), a recently discovered class of regulatory RNAs, are frequently deregulated in cancer and have been suggested to have important roles in cancer initiation and

This paper is one of 6 papers that form part of a special Focus Section on microRNAs. The Guest Editors for this section were Professor Alfredo Fusco, Naples, Italy, and Professor Carlo M Croce, Columbus, $\mathrm{OH}$, USA. development. In ovarian carcinoma, various miRs have been found altered and some of these genes may represent ideal targets for detection, diagnosis, and/or therapy (Bartels \& Tsongalis 2009). In addition, several research groups have observed altered expression of miRs in ovarian cancer and studied their roles in ovarian tumorigenesis. This review will focus on the recent advances in this exciting field.

\section{miRs}

miRs are small non-coding RNAs of 20-22 nucleotides, which were first discovered in Caenorhabditis elegans (Lee et al. 1993) but have now been found to be present and highly conserved among a wide range of species (Wheeler et al. 2009). Similar to other small regulatory RNAs, miRs are generally involved in post-transcriptional gene regulation. miR genes are synthesized in the nucleus by DNA polymerase II as a long double-stranded precursor called primary (pri)-miR that is processed 
by two enzymes, Drosha and Pasha, into a precursor (pre)-miR that is exported to the cytoplasm by exportin 5 (Bohnsack et al. 2004, Cullen 2004, Zeng \& Cullen 2004). Once the pre-miR reaches the cytoplasm, it is cleaved by Dicer into a $\sim 22 \mathrm{nt}$ long functional mature miR. The mature miR can then assemble into a ribonucleoprotein complex known as the RNAinduced silencing complex (RISC) to participate in RNA interference (Pratt \& MacRae 2009). While the exact composition of the RISC is not fully known and may be somewhat variable, the main components are: 1) members of the Argonaute family of proteins, which bind directly to the small regulatory RNA, and 2) a small regulatory RNA (such as miR or siRNA) that directs the complex to its mRNA targets through direct base-pairing. Through the RISC, miRs can downregulate their targets by inhibiting mRNA translation and/or promoting mRNA degradation. The mode of repression may depend, in part, on the level of complementarity of the miRs (with perfect or nearperfect complementarity favoring mRNA degradation). The mechanism of target regulation is complex, but recent work suggests a two-step process by which translation inhibition occurs first and is then followed by mRNA decay due to deadenylation of the mRNA (Fabian et al. 2009). The extent of each of these processes may be variable, and this may account for the observation that target mRNAs are sometimes found to be inhibited exclusively at the mRNA stability level, exclusively at the translational level, or through a combination of both mechanisms.

The $5^{\prime}$ region of a miR, called the 'seed region' (nucleotides 2-8 of the $\mathrm{miR}$ ), is crucial for $\mathrm{miR}$ targeting and function, although other factors are also important (Bartel 2004, Grimson et al. 2007). In mammals, miR target sites are often imperfect and located in the $3^{\prime}$ UTR of the target genes (Gu et al. 2009), although they can also be found in the $5^{\prime}$ UTR or even in the coding region. Because miRs do not require perfect complementarity for functional interactions with mRNA targets, a single miR can regulate multiple targets and conversely, multiple miRs are known to regulate individual mRNAs (Lewis et al. 2003). In addition to downregulating their target genes, miRs have also been reported to activate some targets (Vasudevan et al. 2007).

While miR genes are typically expressed from their own promoters in intergenic regions, a significant portion of miR genes are located within other transcriptional units (Baskerville \& Bartel 2005), usually in intronic regions, but sometimes in exonic regions as well. The exact mechanisms by which these intragenic miRs are processed still remain to be elucidated but appear to be Drosha-independent. The expression of these miRs is coupled with their host genes and subjected to the same regulatory controls (Baskerville \& Bartel 2005). Intronic miRs can regulate genes involved in pathways of the host genes, adding to the complexity of these regulatory loops (Barik 2008).

\section{miR targets}

miRs exert their functions through the regulation of specific sets of target mRNAs. Because of imperfect complementarity requirements and other factors that affect site accessibility, target prediction has been a difficult task particularly (John et al. 2006). Several sequence-matching algorithms, such as TargetScan (Lewis et al. 2003), miRanda (John et al. 2004), RNAhybrid (Rehmsmeier et al. 2004), PicTar (Krek et al. 2005), and DIANA-micro T (Maragkakis et al. 2009) have been developed and are an excellent starting point for identifying putative miR targets. The next generation target prediction and miR databases use combinations of the programs above, as well as additional features such as sequence conservation and gene ontology (Nam et al. 2008b, Roubelakis et al. 2009). It is clear that experimental approaches are necessary in order to identify an accurate full complement of miR targets (John et al. 2006, Creighton et al. 2008), and databases that include lists of experimentally verified miR targets are being constructed (Sethupathy et al. 2006). Similarly, a database that lists miRs that have been implicated in human disease is also available (Jiang et al. 2009).

As indicated above, in addition to computational methods, several functional approaches are being used to identify actual targets of miRs. A straightforward approach consists of over-expressing or down-regulating specific miRs in cultured cells and examining the effects on mRNA and/or protein levels using gene expression profiling or proteomics approaches. This approach was used, for example, to identify mRNAs regulated by $m i R-1$ and $m i R-124$ (Lim et al. 2005), and this was done by over-expressing those miRs and observing the resulting changes in gene expression using microarrays. While this type of experiments identifies regulation at the mRNA stability levels, translational regulation can be addressed by performing proteomics analyses (Grosshans \& Filipowicz 2008). Stable isotope labeling by amino acids in cell culture (SILAC) followed by mass spectroscopy has 
been a particularly useful approach in the investigation of the translational effects of miRs. SILAC has been used to identify miR- 1 targets in HeLa cells (Vinther et al. 2006), and these targets exhibited a significant overlap with targets identified using microarrays. Similarly, other studies confirmed that the levels of hundreds of proteins were affected following changes in the expression of specific miRs (Baek et al. 2008, Selbach et al. 2008). As a whole, these studies showed that miR expression often led to simultaneous mRNA degradation and protein translation inhibition of the targets, and that these effects were dependent on the presence of seed sequences in the $3^{\prime}$ UTR of the target mRNAs.

Finally, a number of biochemical methods have been designed to directly identify the interactions between the miRs and their corresponding targets. For example, labeled/tagged miRs have been used in pull-down experiments to identify mRNAs that these miRs can bind to Orom \& Lund (2007) and Hsu et al. (2009). In addition, it is well known that miRs are part of the RISC complex along with different members of the Argonaute (Ago) family, and this property has been used to enrich for targets of specific miRs. For example, following forced expression of miR-124a, immunoprecipitation of Ago2 led to the enrichment of known miR-124a targets (Karginov et al. 2007). Interestingly, the mRNAs that were significantly enriched by immunoprecipitation included targets that were also down-regulated in total mRNA, and these targets were very likely to contain the seed site. Another approach consists of synthesizing cDNA clones from known mRNA templates using endogenous miRs as primers (Vatolin et al. 2006). Sequencing of the synthesized cDNAs then allows the identification of the miRs as well as the binding sites on the mRNA.

\section{miRs and cancer}

miRs are conserved in distantly related organisms (Wheeler et al. 2009) suggesting important roles in vital cellular processes such as development, differentiation, cell cycle, apoptosis, metabolism, and proliferation (Flynt \& Lai 2008). A possible link between miRs and cancer was first reported in chronic lymphocytic leukemia, where miR-15 and miR-16 were found to be deleted or down-regulated in the vast majority of tumors (Calin et al. 2002). Since then, a large number of studies have found various miRs abnormally expressed in several human malignancies (Zhang et al. 2007). Similar to their protein-coding counterparts, miRs involved in tumorigenesis can be classified as oncogenes or tumor suppressors, depending on their expression pattern and their function (Calin \& Croce 2006a). Several mechanisms leading to abnormal expression of miRs in cancer have been reported, including chromosomal rearrangements (Calin et al. 2005, Tagawa \& Seto 2005, Calin \& Croce 2007), genomic copy number change (Calin et al. 2004, Zhang et al. 2006, Giannakakis et al. 2008), epigenetic modifications (Saito et al. 2006, Iorio et al. 2007), defects in miR biogenesis pathway (Kumar et al. 2007), and regulation by transcriptional factors (He et al. 2007).

Important insights into the mechanisms of miR function in cancer have been provided through the demonstration that miRs are involved in known oncogenic pathways. For example, the three human $R A S$ oncogenes $(H-, K-$, and $N-R A S)$ all contain let-7 sites in their $3^{\prime}$ UTR (Johnson et al. 2005). Interestingly, the let-7 family of miRs, which is typically down-regulated in various tumors, has been shown to negatively regulate the RAS oncogenes in lung tumors, therefore acting as tumor suppressor genes (Johnson et al. 2005, Kumar et al. 2008). Similarly, $m i R-15$ and $m i R-16$ have been shown to target the $B C L 2$ oncogene, leading to its downregulation and apoptosis in leukemic cells (Cimmino et al. 2005). As an example of miRs acting as oncogenes, $m i R-221$ and $m i R-222$ can target and inhibit the expression of the p27Kip tumor suppressor (le Sage et al. 2007). Indeed, high levels of these miRs were shown to maintain low p27 protein and elevated proliferation. Another oncogenic pathway, the p53 pathway, also includes miR components. In fact, the p53 tumor suppressor has been shown to transcriptionally induce $m i R-34$ following genotoxic stress and this induction is important in mediating p53 function (Chang et al. 2007, He et al. 2007, Raver-Shapira et al. 2007, Tarasov et al. 2007).

There is evidence that miR expression patterns may be useful in cancer diagnosis and outcome prediction. Indeed, miR profiling of normal versus tumor tissues using various techniques has consistently shown a large number of deregulated miR genes, most of which are typically down-regulated (Calin \& Croce 2006b). Interestingly, in a pioneering study that included 334 cancer samples from multiple cancers, the global expression patterns of miRs were found to be extremely accurate in distinguishing lineage and differentiation state ( $\mathrm{Lu}$ et al. 2005). Most of the changes were again found to be down-regulation of the miRs and a subsequent study showed that a general down-regulation of miRs in cells (achieved through a 
knockdown of miR processing enzymes) led to enhanced cellular transformation and tumorigenesis, suggesting a crucial role for these genes in the process of transformation (Kumar et al. 2007).

\section{miR expression in ovarian carcinoma}

A number of studies have used various gene expression profiling approaches to study $\mathrm{miR}$ expression in ovarian carcinoma. In order to clearly present these important data, we will describe each study individually. The summary of the differentially expressed miRs for each study is included in Table 1.

\section{Integrative analysis of miR changes in ovarian carcinoma}

An integrative genomic approach that included miR microarray, array-based comparative genomic hybridization, cDNA microarray, and tissue array was used to evaluate miR changes in epithelial ovarian cancer (Zhang et al. 2008). The authors found that both genomic losses and epigenetic alterations may be responsible for miR down-regulation. Out of $35 \mathrm{miRs}$ deregulated between ovarian carcinoma and the normal controls (immortalized ovarian surface epithelial cells), $31(88.6 \%)$ were down-regulated in cancer tissues compared with non-cancer tissues. The downregulated genes included miRs let-7d and miR-127, which had been previously implicated in cancer. Thirteen miRs were down-regulated in high-grade tumors compared with low-grade tumors. Furthermore, down-regulation was higher in late-stage cancers as compared with early-stage cancers, suggesting a tumor suppressor function for the down-regulated miRs. Among 44 miRs down-regulated in late-stage tumors, three miRs, $m i R-15 a, m i R-34 a$, and $m i R-34 b$ are believed to be tumor suppressors.

The region containing $m i R-182$ was amplified in $28.9 \%$ of EOC, implying an oncogene-type function for this miR, whereas, miR-15a was deleted in $23.9 \%$ of EOC suggesting a tumor suppressive role. DNA copy number amplification and deletion were correlated with $m i R-182$ and $m i R-15 a$ expressions respectively, in both primary tumors and cell lines. However, DNA copy number changes could explain the expression of only 6 of the 33 abnormally expressed miRs. EOC cell lines that were treated with DNA demethylating and histone deacetylase (HDAC) inhibitors exhibited up-regulation of 16 miRs, which suggests epigenetic modification as another crucial factor determining the expression of miRs in EOC. In the tumors, loss of $m i R-377, m i R-368$, and $m i R-495$ cluster, which is localized at Dlkl-Gtl2 domain, results in higher proliferation and in shorter survival of the patients (Zhang et al. 2008).

\section{Genome-wide analysis of miR copy number abnormalities in ovarian carcinoma}

Using array-based comparative genomic hybridization, these authors found that genomic regions containing miR genes frequently exhibited copy number abnormalities (Zhang et al. 2006). In particular, copy number losses of the region containing $m i R-218-1$ and SLIT2 were observed in $15.5 \%$ of ovarian carcinomas. There was a positive correlation between miR copy number changes and the miR expression levels of $73.1 \%$ of the miR genes. In addition, experiments with demethylating agents suggested that up to $33 \%$ of miRs may be regulated by epigenetic mechanisms.

\section{Hypoxia-responsive miRs in ovarian carcinoma}

The screening of a panel of 157 miRs allowed the identification of $m i R-210$ as the most highly and consistently up-regulated $\mathrm{miR}$, following hypoxia induction (Giannakakis et al. 2008). Interestingly, $m i R-210$ is located at chromosome $11 \mathrm{p} 15.5$ within a frequent region of loss of heterozygosity in ovarian carcinoma. The gene copy number of $m i R-210$ was reduced in $64 \%$ of ovarian carcinomas, and these alterations were associated with decreased levels of $m i R-210$, suggesting a tumor suppressive function for this gene.

\section{miR expression signature in ovarian carcinoma}

In another study, 15 normal ovarian samples, 69 ovarian malignant tumors, and five ovarian carcinoma cell lines were studied by miR microarray analysis (Iorio et al. 2007). The unsupervised hierarchical clustering classified the samples into two distinct categories representing 'normal' and 'cancer samples/ cell lines'. A total of 29 and 39 miRs were found to be aberrantly expressed by significance analysis of microarrays (SAM) and prediction analysis of microarrays (PAM) analysis respectively. MiR-200a and $m i R-141$ were highly up-regulated, whereas $m i R-199 a, m i R-140, m i R-145$, and $m i R-125 b 1$ were most significantly down-regulated. Although some of the miRs were deregulated in all the subtypes, certain miRs could differentiate different subtypes (serous, endometrioid, and clear cell) of ovarian carcinomas. For example, $m i R-200 a$ and $m i R-200 c$ were upregulated in all the three subtypes, $m i R-200 b$ and $m i R-141$ were up-regulated in serous as well as endometrioid, and $m i R-21, m i R-203$, and $m i R-205$ were up-regulated only in endometrioid. Among the 
Table 1 MicroRNAs (miRs) with altered expression in ovarian carcinoma

\begin{tabular}{|c|c|c|c|}
\hline Up-regulated & Down-regulated & Comparison & Reference \\
\hline $\operatorname{miR}-221, \operatorname{miR}-146 b, \operatorname{miR}-508$ & $\begin{array}{l}\text { let-7f, miR-106b, miR-134, miR-155, } \\
\text { miR-21, miR-346, miR-422a, miR-424, } \\
\text { miR-519a, miR-648, miR-662 }\end{array}$ & $\begin{array}{l}\text { Ovarian carcinoma cell } \\
\text { lines and tissues } \\
\text { versus normal }\end{array}$ & $\begin{array}{l}\text { Dahiya et al. } \\
\text { (2008) }\end{array}$ \\
\hline $\begin{array}{l}\text { miR-26b, miR-182, } \\
\text { miR-103, miR-26a }\end{array}$ & $\begin{array}{l}\text { miR-127, miR-134, miR-154*, miR-410, } \\
\text { miR-377, miR-100, miR-432, miR-368, } \\
\text { miR-154, miR-495, miR-376a, } \\
\text { miR-323, miR-376b, miR-370, } \\
\text { miR-299, let7d, miR-155, miR-140, } \\
\text { miR-222, miR-337, miR-124a, } \\
\text { miR-99a, miR-331, miR-104, miR-150, } \\
\text { miR-184, miR-152, miR-145, miR-424, } \\
\text { miR-224, miR-302c }\end{array}$ & $\begin{array}{l}\text { EOC cell lines versus } \\
\text { normal }\end{array}$ & $\begin{array}{l}\text { Zhang et al. } \\
\qquad(2008)\end{array}$ \\
\hline None & $\begin{array}{l}\text { miR-509, miR-514, miR-513, miR-196, } \\
\text { miR-376a, miR-184, miR-519d, miR- } \\
\text { 495, miR-424, miR-1, miR-368 miR-362 } \\
\text { miR-22, miR-376b, miR-337, miR-133a, } \\
\text { miR-508, miR-492, miR-137, miR-95, } \\
\text { miR-448, miR-518, miR-491, miR-455, } \\
\text { miR-365, miR-147, miR-488, miR-34a, } \\
\text { miR-372, miR-202, miR-503, miR-520e, } \\
\text { miR-410, miR-519e, miR-375, miR-346, } \\
\text { miR-15a, miR-507, miR-450, miR-377, } \\
\text { miR-34b, miR-518a, miR-432, miR-516 }\end{array}$ & $\begin{array}{l}\text { Early-stage cancer } \\
\text { versus late-stage } \\
\text { cancer }\end{array}$ & $\begin{array}{l}\text { Zhang et al. } \\
\qquad(2008)\end{array}$ \\
\hline None & $\begin{array}{l}\text { miR-514, miR-509, miR-508, miR-34c, } \\
\text { miR-513, miR-368, miR-379, miR-154, } \\
\text { miR-337, miR-507, miR-503, miR-376 }\end{array}$ & $\begin{array}{l}\text { Low-grade cancer versus } \\
\text { high-grade cancer }\end{array}$ & $\begin{array}{l}\text { Zhang et al. } \\
\qquad(2008)\end{array}$ \\
\hline $\begin{array}{l}\operatorname{miR}-200 b, \operatorname{miR}-21, \operatorname{miR}-200 c \\
\operatorname{miR}-141, \operatorname{miR}-20 a, \operatorname{miR}-27 a \\
\operatorname{miR}-16, \operatorname{miR}-93\end{array}$ & $\begin{array}{l}\text { miR-145, miR-125b, miR-100, miR-99a, } \\
\text { miR-26a, miR-10b, miR-143, miR-214, } \\
\text { let-7b, miR-29a, miR-125a }\end{array}$ & $\begin{array}{l}\text { Serous ovarian } \\
\text { carcinoma versus } \\
\text { normal ovarian tissues }\end{array}$ & $\begin{array}{r}\text { Nam et al. } \\
(2008 a)\end{array}$ \\
\hline $\begin{array}{l}\text { miR-182, miR-200c, miR-142-3p, } \\
\text { miR-200b, miR-135b, } \\
\text { miR-200a, miR-195, miR-126*, } \\
\text { miR-26b, miR-10b, miR-126, miR-199b- } \\
\text { 5p, miR-107, miR-30b, miR-192, } \\
\text { miR-335, miR-32, miR-20a, miR-30c, } \\
\text { miR-143, miR-92a, miR-199b-3p, } \\
\text { miR-99a, miR-26a, miR-18a, miR-16, } \\
\text { miR-15a, miR-30e, miR-194, miR-29c, } \\
\text { miR-30d, miR-106b }\end{array}$ & $\begin{array}{l}m i R-127-3 p, m i R-377^{*}, \text { miR-382, } \\
\text { miR-493, miR-409-3p, miR-193a-5p, } \\
\text { miR-210, miR-935, miR-100, miR-31, } \\
\text { miR-22, miR-152, miR-379, miR-185, } \\
\text { miR-221, miR-744, miR-21*, let-7a*, } \\
\text { miR-574-5p, miR-31*, miR-130b, } \\
\text { miR-149, miR-423-5p, } \\
\text { miR-1308, miR-629, miR-320a }\end{array}$ & $\begin{array}{l}\text { Stage III/IV epithelial } \\
\text { ovarian carcinoma } \\
\text { versus normal (only } \\
\text { miRs differentially } \\
\text { expressed between all } \\
\text { OC subtypes versus } \\
\text { normal are included in } \\
\text { this table) }\end{array}$ & $\begin{array}{l}\text { Wyman et al. } \\
\text { (2009) }\end{array}$ \\
\hline $\begin{array}{l}\text { miR-223, miR-206, let-7i, miR-30a3p, } \\
\text { miR-368, miR-10b, miR-338, miR-195, } \\
\text { miR-93, miR-23a, miR-185, miR-22, } \\
\text { miR-339, miR-321, miR-29b, miR-186, } \\
\text { miR-128a, miR-374, miR-193, miR-106b, } \\
\text { miR-194, miR-370, miR-128b, miR-198, } \\
\text { miR-224, miR-222, miR-29c, miR-21, } \\
\text { miR-34c, miR-139, miR-197, miR-15a, } \\
\text { miR-218, miR-106a, miR-340, } \\
\text { miR-219, miR-155, miR-92, let-7g, } \\
\text { miR-328, miR-149, miR-23b, miR-221, } \\
\text { miR-150, miR-190, miR-107, miR-331, } \\
\text { miR-181c, miR-133b }\end{array}$ & $\begin{array}{l}\text { miR-326, miR-30d, miR-125b, } \\
\text { miR-31, miR-99a, miR-100, } \\
\text { miR-137, miR-9 }\end{array}$ & $\begin{array}{l}\text { Primary versus recurrent } \\
\text { serous papillary ovar- } \\
\text { ian carcinomas }\end{array}$ & $\begin{array}{l}\text { Laios et al. } \\
\qquad(2008)\end{array}$ \\
\hline $\begin{array}{c}m i R-200 a, m i R-200 b \\
m i R-200 c, m i R-141\end{array}$ & $\begin{array}{l}\text { miR-140, miR-199a, miR-199b, } \\
\quad \text { miR-145, miR-143, miR-125a, } \\
\quad \text { miR-125b, miR-101, miR-212, miR-222 }\end{array}$ & Normal versus cancer & $\begin{array}{l}\text { Iorio et al. } \\
\quad(2007)\end{array}$ \\
\hline $\begin{array}{l}\text { miR-199a, miR-424, miR-302d, miR-320, } \\
\text { miR-214, miR-200a, miR-29a }\end{array}$ & $\begin{array}{l}m i R-493, \text { miR-494, miR-125b } \\
\quad m i R-100, \text { let-7a, let-7b, let-7c }\end{array}$ & $\begin{array}{l}\text { Normal versus primary } \\
\text { tumors }\end{array}$ & $\begin{array}{l}\text { Yang et al. } \\
(2008 a)\end{array}$ \\
\hline
\end{tabular}


down-regulated miRs, $m i R$-145 was down-regulated in serous and clear cell carcinomas, while $m i R-222$ was down-regulated in both endometrioid and clear cell carcinomas. miR expression profiles were not dependent on the grade or stage of the disease. The treatment of ovarian carcinoma cell lines with the demethylating agent 5-aza- $2^{\prime}$-deoxycytidine resulted in induction of $m i R-21, m i R-203, m i R-146 b, m i R-205, m i R-30-5 p$, and $m i R-30 c$. Since $m i R-21, m i R-203$, and $m i R-205$ were observed over-expressed in ovarian carcinoma, these experiments suggest that hypomethylation could be responsible for the observed expression patterns of these miRs in cancer. However, it was also interesting to observe that the most significantly up-regulated miRs belong to the same family and were localized in pairs: $m i R-200 a$ and $m i R-200 b$ at chromosome $1 \mathrm{p} 36.33$, and $m i R-200 \mathrm{c}$ and $m i R-141$ at chromosome $12 \mathrm{p} 13.31$. This study is consistent with others showing that mechanisms of miR deregulation in ovarian carcinoma include copy number changes as well as epigenetic mechanisms (Zhang et al. 2006, 2008).

\section{Identification of differentially expressed miRs in ovarian carcinoma and identification of PTEN as a target of miR-214}

Using miR microarrays, 36 miRs were found deregulated between normal ovarian cells and epithelial ovarian tumors, with $m i R-199 a^{*}, m i R-214$, $m i R-200 a$, and miR-100 being the most highly differentially expressed candidates (Yang et al. 2008a). miR-199a*, miR-214, and $m i R-200 a$ were up-regulated in 53, 56, and $43 \%$ tumor tissues respectively, and their expression was associated with high-grade and late-stage tumors. $m i R-100$ was down-regulated in $76 \%$ of tumors. The authors selected miR-214 for further study and found PTEN as one of its potential targets, implicating this $\mathrm{miR}$ in the regulation of the AKT survival pathway.

\section{miR expression profiles in serous ovarian carcinoma}

In this study, 23 miRs were found aberrantly expressed in at least $60 \%$ of ovarian cancer samples (Nam et al. 2008a). Among 11 up-regulated miRs, miR-21 topped the list showing its expression in $85 \%$ samples; whereas among 12 down-regulated, miR-125b was the most significant and exhibited down-regulation in $95 \%$ tumor samples. Fifty percent of miRs reported in this study were also found in the Iorio study (Iorio et al. 2007). The most significantly altered miRs in both studies were: $m i R-200 a / b / c, m i R-141, m i R-21, m i R-145$, $m i R-99 a$, let-7, and $m i R-125 b$.

\section{Identification of miRs that are differentially expressed in ovarian carcinoma: importance of the let-7 family}

Our laboratory investigated $\mathrm{miR}$ expression profiles in 34 ovarian carcinoma tissues as well as ten ovarian carcinoma cell lines (Dahiya et al. 2008). A total of 25 up-regulated and 31 down-regulated miRs were identified. We also found five up-regulated and 23 down-regulated miRs in ovarian carcinoma cell lines compared with non-neoplastic cells. Fourteen miRs were deregulated in both tissues and cell lines (Table 1). MiR-221 was the most highly elevated miR in both tissues and cell lines (ninefold and sevenfold respectively), while $m i R-21$ was significantly decreased in both sample types (threefold and ninefold respectively). Among the different let-7 family members, let-7e and let-7f showed more than twofold deregulation in at least $60 \%$ of the tumor samples. The other let-7 family members (let-7g, let-7d, let-7c, let-7a-e, let-7i, let-7a, and let-7b) were not down-regulated as consistently, but each one of them was found decreased twofold or more in at least $20 \%$ of the tumors. Overall, $94 \%$ of the tumors had at least one let-7 family member down-regulated at least twofold. Cell lines exhibited down-regulation of the let-7 family members as well. This study suggested an important role for let-7 family members in ovarian carcinoma.

\section{Comprehensive analysis of $\mathrm{miR}$ repertoire in ovarian carcinoma using massively parallel sequencing technologies}

Using novel massively parallel sequencing technology (454 sequencing) to sequence small RNA cDNA libraries derived from epithelial ovarian cancers and normal samples, this group was able to generate comprehensive miR digital profiles for these tissues (Wyman et al. 2009). In their data, the investigators identified 498 previously annotated miRs, six novel and 39 candidate miRs. They found 124 miRs that were differentially expressed in cancers of various subtypes compared with the normal ovarian cells. A subset of 37 miRs were over-expressed in all epithelial ovarian cancer subtypes and 21 were under-expressed (Table 1). Among those, several were validated by RT-PCR. The validated over-expressed miRs included several members of the miR-200 family, while the downregulated genes included $m i R-100, m i R-210, m i R-22$, and $m i R-222$. 


\section{Roles of miRs in ovarian carcinoma chemotherapy}

Cisplatin is the most efficacious chemotherapeutic agent against ovarian carcinoma with initial response rates varying between 40 and $80 \%$ (Ozols \& Young 1984). Platinum-based combination therapy, especially carboplatin/paclitaxel, offers a modest but significant improvement over cisplatin alone, and this regimen is now standard for women with advanced epithelial ovarian cancer (McGuire et al. 1996). Unfortunately, many women with tumors that initially respond to chemotherapy eventually relapse with drug-resistant disease (Ozols \& Young 1984). Overall, fewer than $25 \%$ of the women diagnosed with advanced ovarian carcinoma will show progression-free survival after 4 years, in spite of treatment (McGuire et al. 1996). In this context, a better understanding of drug resistance may lead to the development of novel approaches for the treatment of ovarian and other cancers. A number of investigators have now reported possible roles for $\mathrm{miR}$ in the establishment of drug resistance in ovarian cancer.

In a recent report where primary and recurrent cases of ovarian cancers were compared, $60 \mathrm{miRs}$ were found deregulated more than twofold between primary and recurrent disease (Laios et al. 2008). In contrast to several studies reporting a majority of miRs to be down-regulated in cancer tissues, a marked up-regulation of miRs in recurrent compared with primary tumors was observed (52 miRs showed overexpression and 8 showed under-expression of $>$ twofold in recurrent versus primary tumors). $m i R-223$ (up) and $m i R-9$ (down) were the most highly deregulated genes in the recurrent versus primary samples (Laios et al. 2008).

When cisplatin resistance was specifically examined for miR expression, and tumors from responders were compared with those of non-responders, 34 statistically significant changes were found $(24 \mathrm{miRs}$ were higher in the non-response group and 10 were higher in the complete response group; Yang et al. 2008b). Let-7i was the most down-regulated $\mathrm{miR}$ in the chemotherapy resistant patients. In addition, functional analyses confirmed that reduced let-7i expression increased the resistance of ovarian and breast cancer cells to cisplatin. In another study, elevation of $m i R-214$ was found to be responsible for development of resistance against cisplatin (Yang et al. 2008a). $m i R-214$ also has anti-apoptotic functions, as blocking $m i R$ - 214 expression made A2780 cells more sensitive to cisplatin-induced apoptosis (Yang et al. 2008a). Another expression profiling study in a panel of cisplatin-, paclitaxel-, and cyclosporin A-resistant ovarian carcinoma cells revealed the expressions of let-7e, miR-30c, miR-125b, miR-130a, and miR-335 in all the resistant cell lines (Sorrentino et al. 2008). While analyzing their downstream targets, the investigators found a direct relationship between downregulation of $m i R-130 a$ with up-regulation of $M-C S F$, a gene already known to be up-regulated in ovarian carcinoma.

\section{miR targets and pathways in ovarian carcinoma}

There have been relatively few miR targets that have been specifically shown to be relevant to ovarian tumorigenesis, but work in other systems allows us to make educated guesses concerning the pathways and targets of some of the miRs found aberrantly expressed in ovarian carcinoma (Fig. 1). For example, the $R A S$ oncogenes are well-known targets of the let-7 cluster (Johnson et al. 2005), which have been reported to be down-regulated in ovarian carcinoma by several groups (Table 1). Other let-7 targets, such as $H M G A 2, C D K 6$, and $c M Y C$, are likely relevant to tumorigenesis (Peter 2009). Similarly, the tumor suppressor gene WT1, which encodes a transcription factor, is a putative target of $m i R-212$.

Unlike the previous examples, which were elucidated in other systems, $m i R-214$ was shown to target PTEN in ovarian carcinoma, explaining its ability to regulate survival and drug resistance (Yang et al. 2008a). The p53 pathway is another pathway with important miR components that were studied in ovarian carcinoma. $m i R-34 b$ and $m i R-34 c$, two known transcriptional targets of $\mathrm{p} 53$, have been shown to be down-regulated in ovarian carcinoma (Zhang et al. 2008). Interestingly, their overexpression can suppress proliferation and colony formation in soft agar in neoplastic epithelial ovarian cells, providing functional relevance of this pathway in ovarian tumorigenesis (Corney et al. 2007). miR-146 was found elevated in epithelial ovarian cancer (Volinia et al. 2006) and may target BRCAl and BRCA2 (Shen et al. 2008), two well-documented tumor suppressors in breast and ovarian cancers (Fig. 2).

In a recent study, putative targets for a number of miR genes were identified using a microarray approach in ovarian carcinoma cells (Dahiya et al. 2008). Intriguingly, the experimental targets varied depending on the cell line used for the experiment, suggesting a significant influence of the molecular background on miR target selection. It will therefore be important to methodically study each miRs in several ovarian 


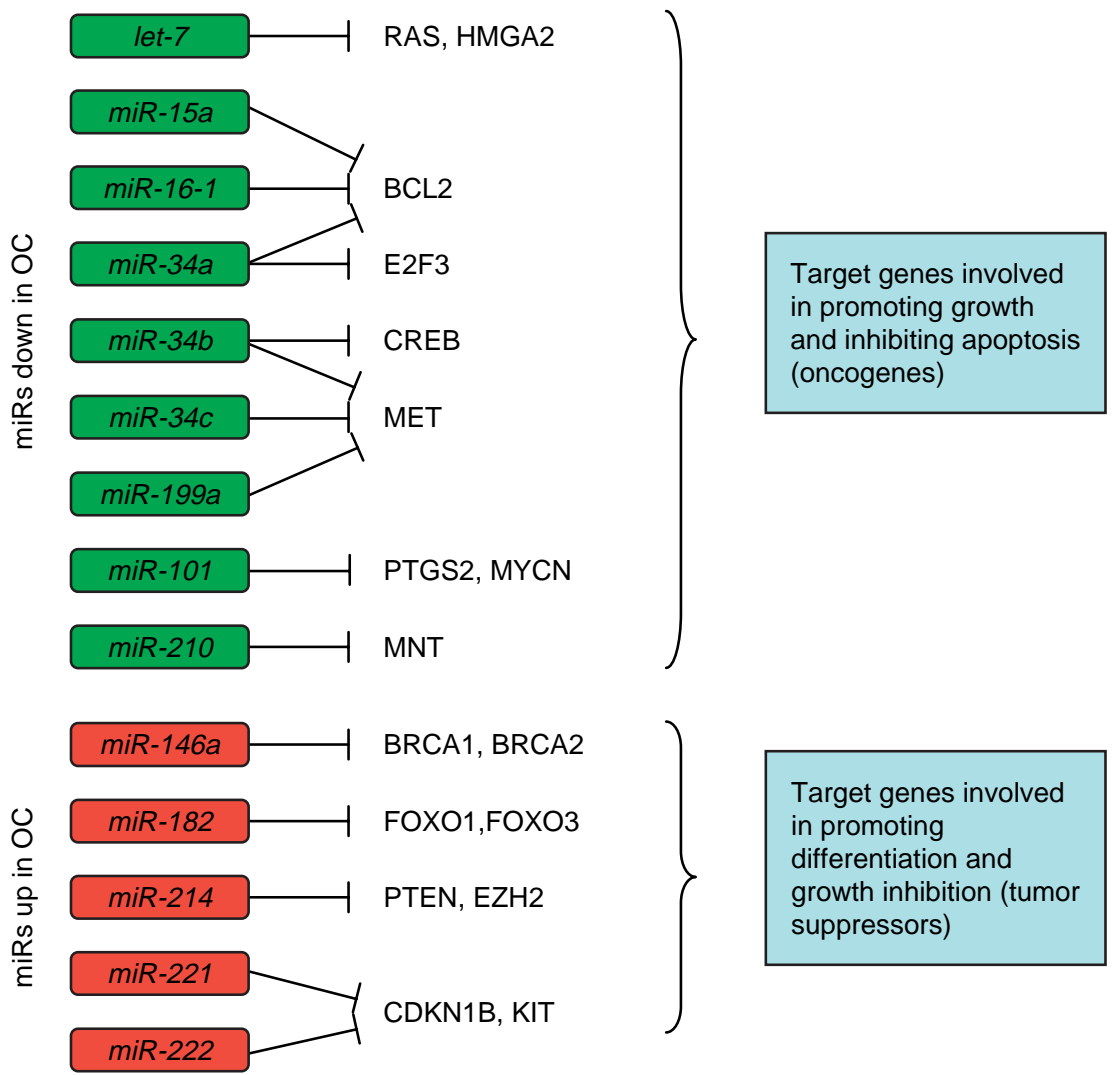

Figure 1 Schematic representation of selected known targets for miRs that are frequently altered in ovarian carcinoma. The miRs frequently down-regulated in ovarian carcinoma (shown in green boxes) typically target genes that have growth promoting functions, while miRs that are up-regulated (red boxes) target genes that have negative effects on cell growth. These miRs may represent targets for therapeutic interventions.

models in order to fully understand their roles in ovarian carcinoma. These findings also imply that targets identified in other cell models may not necessarily be relevant to ovarian cancer.

\section{miRs in detection and diagnosis of ovarian carcinoma}

A number of studies have shown that miRs may be useful in predicting ovarian carcinoma outcome. For example, it was shown that patients with low let-7a-3 methylation had worse overall survival than those with high methylation (Lu et al. 2007). In another study, the miR-200b-429 cluster, which harbors $m i R-200 a, m i R-200 b$, and $m i R-429$, could predict poor survival when the $m i R-200$ genes were expressed at low levels (Hu et al. 2009). The targets of $m i R-200$ miRs have known roles in cancer development. A promising study reported that the HMGA2/let-7 ratio was able to categorize ovarian carcinoma patients into two groups with significantly different prognosis (Shell et al. 2007). The group with lower HMGA2/let-7 ratio exhibited increased 5-year progression-free survival $(\sim 40 \%)$ compared with the group with a higher HMGA2/let-7 ratio $(<10 \%)$. Another study showed that $m i R-214, m i R-199 *$, and $m i R-200 a$ were associated with high-grade and late-stage tumors (Yang et al. 2008a). Tumors with higher expression of $m i R-200 a$ had a median overall survival of 27.5 months compared with 61 months for those with no significant expression (Nam et al. 2008a). Interestingly, polymorphisms in miRs may affect their function and be of prognostic value. For example, the precursor miR-146a, which targets $B R C A 1$ and $B R C A 2$, exhibits a $\mathrm{G}$ to $\mathrm{C}$ polymorphism in ovarian and breast cancers (Shen et al. 2008). This polymorphism results in a change from $\mathrm{G}: \mathrm{U}$ pair to a $\mathrm{C}: \mathrm{U}$ mismatch in the miR stem region. Ovarian cancer patients showing $\mathrm{G}$ to $\mathrm{C}$ polymorphism were typically diagnosed younger than the patients having common mir-146a allele (Shen et al. 2008). Additionally, with the presence of the variant allele, there was increased production of mature mir-146a that may be responsible for early onset of the disease. 


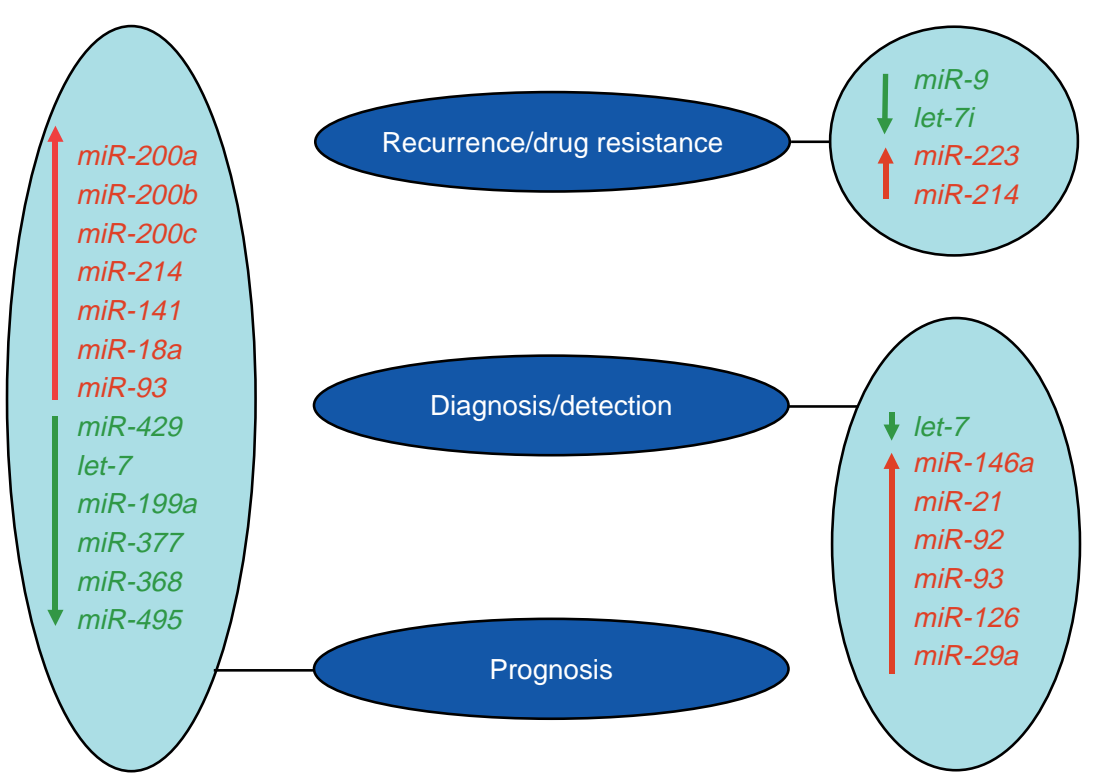

Figure 2 miRs with potential clinical use in ovarian carcinoma. List of miRs with potential roles in recurrence/drug resistance (Laios et al. 2008, Yang et al. 2008a,b), diagnosis/detection (Shell et al. 2007, Shen et al. 2008), prognosis (Nam et al. 2008a, Yang et al. 2008a, Zhang et al. 2008) of ovarian cancer. miRs indicated in green are typically down-regulated in ovarian carcinoma, while miRs indicated in red are up-regulated.

Interestingly, miRs can also be detected in serum samples (Feng et al. 2008, Lawrie et al. 2008, Lodes et al. 2009), suggesting that they may represent useful detection biomarkers. By RT-PCR analysis, $m i R-21$, $m i R-92, m i R-93, m i R-126$, and $m i R-29 a$ were found up-regulated, while $m i R-155, m i R-127$, and $m i R-99 b$ were found down-regulated in serum collected from ovarian carcinoma patients (Resnick et al. 2009). Up-regulation of $m i R-21, m i R-92$, and $m i R-93$ in the serum of three cancer patients with normal CA-125 level suggests that miRs may be complementary to current detection approaches. Interestingly, circulating tumor-derived exosomes (small lipid vesicles) have been found to contain miRs that could potentially be used as detection and/or diagnostic markers (Taylor \& Gercel-Taylor 2008). The use of exosomes-derived miRs in diagnosis may circumvent the need for biopsy material.

\section{Therapeutic potential of miRs}

Because of their properties, miRs have been suggested as possible therapeutic tools. The approaches suggested include manipulating the expression of tumor suppressor or oncogenic miRs (Mishra \& Merlino 2009) using specific miR to down-regulate oncogenic genes (Cimmino et al. 2005) and using miR to confer tissue specificity to transgene expression in gene therapy (Brown \& Naldini 2009). When considering altering miR expression for therapeutic purposes, the regulation of multiple genes by a single miR suggests the possible targeting of pathways involved in the development or progression of the disease. Normal levels of tumor suppressor miRs that are down-regulated in cancer could potentially be restored by over-expression (Mishra \& Merlino 2009). miRs can be introduced into cells by infecting cells with retrovirus or lentivirus expressing the miR of interest. This method has the advantage of making the system inducible or cell-specific, thereby reducing toxicity. For miRs that are over-expressed in cancer, miR inhibitors can be used to modulate their levels. For example, sequence-specific antisense oligonucleotides against an individual $\mathrm{miR}$ can be transfected into mammalian cells, preventing the miR from binding its targets (Hutvagner et al. 2004, Meister et al. 2004, Horwich \& Zamore 2008). Another approach consists of high expression of artificial target genes containing multiple tandem binding sites for the miR of interest (Ebert et al. 2007). This competitive inhibition approach, known as 'miR sponge', results in the release of miR-mediated repression of endogenous targets (Ebert et al. 2007). While the specific targets useful for ovarian cancer therapy remain to be determined, miR-31 inhibition using a 'sponge' strategy has recently been shown to inhibit breast cancer metastasis in vivo (Valastyan et al. 2009). 
The determination of useful miR targets for therapy will likely be a major focus of future research in ovarian cancer.

In addition, miRs against known oncogenes could potentially be used to repress the expression of these genes in tumors. For example, over-expression of $m i R$ 15 and miR-16 was shown to induce apoptosis in leukemic cells through the ability of these miRs to target BCL2 (Cimmino et al. 2005). Similarly, miR-34a was shown to target $E 2 F 3$ and induce apoptosis in neuroblastoma cells (Welch et al. 2007). In ovarian carcinoma, let-7 is commonly down-regulated and is shown to target HMGA2 (Shell et al. 2007), a gene that may be responsible for de-differentiation during ovarian carcinoma progression (Park et al. 2007, Shell et al. 2007). Re-introduction of let-7 has therefore been suggested as a possible approach for the therapy of ovarian carcinoma (Park et al. 2007).

Finally, miR may be useful in ensuring tight tissuespecific control of transgene expression in gene therapy. Indeed, by incorporating carefully chosen specific miR target sites into a therapeutic mRNA, it may be possible to inhibit this mRNA in tissues where its expression is not wanted, thereby minimizing its toxicity and side effects (Brown \& Naldini 2009). In cancer, expression of a toxic gene such as thymidine kinase, or re-expression of a tumor suppressor gene, could potentially be made more specific by including, in these transgenes, sites for miRs that are expressed in normal tissues, but not in cancer cells. Clearly, a detailed knowledge of miR expression in normal and neoplastic tissues will be crucial for the success of these approaches.

\section{Perspectives}

While a large amount of information have been gained on the roles and possible therapeutic use of miRs in ovarian carcinoma, much remain to be done. In particular, more thorough miR expression profiling will be necessary to clarify expression in ovarian carcinoma of various grades, stages, or drug resistance status. The next step, the identification of relevant targets, will likely be a tedious task, complicated by the fact that miRs can have several functional targets and that these targets may be dependent on several factors, including the expression of other miRs. Once relevant miRs and functional targets are identified, the investigation of possible clinical use for these molecules will represent the next frontier, and may, ultimately lead to novel strategies for ovarian cancer detection and therapy.

\section{Declaration of interest}

The authors declare that there is no conflict of interest that could be perceived as prejudicing the impartiality of the research reported.

\section{Funding}

This work was supported entirely by the Intramural Research Program of the National Institutes of Health, National Institute on Aging.

\section{Acknowledgements}

We thank Drs Ashani Weeraratna and Myriam Gorospe, as well as the members of our laboratory for helpful comments on the manuscript.

\section{References}

Ahmed FY, Wiltshaw E, A'Hern RP, Nicol B, Shepherd J, Blake P, Fisher C \& Gore ME 1996 Natural history and prognosis of untreated stage I epithelial ovarian carcinoma. Journal of Clinical Oncology 14 2968-2975.

Baek D, Villen J, Shin C, Camargo FD, Gygi SP \& Bartel DP 2008 The impact of microRNAs on protein output. Nature 455 64-71.

Barik S 2008 An intronic microRNA silences genes that are functionally antagonistic to its host gene. Nucleic Acids Research 36 5232-5241.

Bartel DP 2004 MicroRNAs: genomics, biogenesis, mechanism, and function. Cell 116 281-297.

Bartels CL \& Tsongalis GJ 2009 MicroRNAs: novel biomarkers for human cancer. Clinical Chemistry $\mathbf{5 5}$ 623-631.

Baskerville S \& Bartel DP 2005 Microarray profiling of microRNAs reveals frequent coexpression with neighboring miRNAs and host genes. RNA 11 241-247.

Bohnsack MT, Czaplinski K \& Gorlich D 2004 Exportin 5 is a RanGTP-dependent dsRNA-binding protein that mediates nuclear export of pre-miRNAs. RNA 10 185-191.

Brown BD \& Naldini L 2009 Exploiting and antagonizing microRNA regulation for therapeutic and experimental applications. Nature Reviews. Genetics 10 578-585.

Calin GA \& Croce CM $2006 a$ MicroRNA-cancer connection: the beginning of a new tale. Cancer Research $\mathbf{6 6}$ 7390-7394.

Calin GA \& Croce CM $2006 b$ MicroRNA signatures in human cancers. Nature Reviews. Cancer 6 857-866.

Calin GA \& Croce CM 2007 Chromosomal rearrangements and microRNAs: a new cancer link with clinical implications. Journal of Clinical Investigation $\mathbf{1 1 7}$ 2059-2066.

Calin GA, Dumitru CD, Shimizu M, Bichi R, Zupo S, Noch E, Aldler H, Rattan S, Keating M, Rai K et al. 2002 Frequent deletions and down-regulation of micro-RNA genes miR15 and miR16 at 13q14 in chronic lymphocytic leukemia. PNAS 99 15524-15529. 
Calin GA, Sevignani C, Dumitru CD, Hyslop T, Noch E, Yendamuri S, Shimizu M, Rattan S, Bullrich F, Negrini M et al. 2004 Human microRNA genes are frequently located at fragile sites and genomic regions involved in cancers. PNAS 101 2999-3004.

Calin GA, Ferracin M, Cimmino A, Di Leva G, Shimizu M, Wojcik SE, Iorio MV, Visone R, Sever NI, Fabbri M et al. 2005 A microRNA signature associated with prognosis and progression in chronic lymphocytic leukemia. New England Journal of Medicine 353 1793-1801.

Chang TC, Wentzel EA, Kent OA, Ramachandran K, Mullendore M, Lee KH, Feldmann G, Yamakuchi M, Ferlito M, Lowenstein CJ et al. 2007 Transactivation of miR-34a by p53 broadly influences gene expression and promotes apoptosis. Molecular Cell 26 745-752.

Cimmino A, Calin GA, Fabbri M, Iorio MV, Ferracin M, Shimizu M, Wojcik SE, Aqeilan RI, Zupo S, Dono M et al. $2005 \mathrm{miR}-15$ and miR-16 induce apoptosis by targeting BCL2. PNAS 102 13944-13949.

Corney DC, Flesken-Nikitin A, Godwin AK, Wang W \& Nikitin AY 2007 MicroRNA-34b and microRNA-34c are targets of p53 and cooperate in control of cell proliferation and adhesion-independent growth. Cancer Research 67 8433-8438.

Creighton CJ, Nagaraja AK, Hanash SM, Matzuk MM \& Gunaratne PH 2008 A bioinformatics tool for linking gene expression profiling results with public databases of microRNA target predictions. RNA 14 2290-2296.

Cullen BR 2004 Transcription and processing of human microRNA precursors. Molecular Cell 16 861-865.

Dahiya N, Sherman-Baust CA, Wang TL, Davidson B, Shih Ie M, Zhang Y, Wood W III, Becker KG \& Morin PJ 2008 MicroRNA expression and identification of putative miRNA targets in ovarian cancer. PLoS ONE 3 e2436.

Ebert MS, Neilson JR \& Sharp PA 2007 MicroRNA sponges: competitive inhibitors of small RNAs in mammalian cells. Nature Methods 4 721-726.

Fabian MR, Mathonnet G, Sundermeier T, Mathys H, Zipprich JT, Svitkin YV, Rivas F, Jinek M, Wohlschlegel J, Doudna JA et al. 2009 Mammalian miRNA RISC recruits CAF1 and PABP to affect PABP-dependent deadenylation. Molecular Cell 35 868-880.

Feng G, Li G, Gentil-Perret A, Tostain J \& Genin C 2008 Elevated serum-circulating RNA in patients with conventional renal cell cancer. Anticancer Research $\mathbf{2 8}$ 321-326.

Flynt AS \& Lai EC 2008 Biological principles of microRNAmediated regulation: shared themes amid diversity. Nature Reviews. Genetics 9 831-842.

Fung-Kee-Fung M, Oliver T, Elit L, Oza A, Hirte HW \& Bryson P 2007 Optimal chemotherapy treatment for women with recurrent ovarian cancer. Current Oncology 14 195-208.

Garcia M, Jemal A, Ward EM, Center MM, Hao Y, Siegel R \& Thun MJ 2007 In Global Cancer Facts \& Figures 2007 Available: www.cancer.org. Atlanta, GA: American Cancer Society.
Giannakakis A, Sandaltzopoulos R, Greshock J, Liang S, Huang J, Hasegawa K, Li C, O’Brien-Jenkins A, Katsaros D, Weber BL et al. 2008 miR-210 links hypoxia with cell cycle regulation and is deleted in human epithelial ovarian cancer. Cancer Biology \& Therapy 7 255-264.

Grimson A, Farh KK, Johnston WK, Garrett-Engele P, Lim LP \& Bartel DP 2007 MicroRNA targeting specificity in mammals: determinants beyond seed pairing. Molecular Cell 27 91-105.

Grosshans H \& Filipowicz W 2008 Proteomics joins the search for microRNA targets. Cell 134 560-562.

Gu S, Jin L, Zhang F, Sarnow P \& Kay MA 2009

Biological basis for restriction of microRNA targets to the $3^{\prime}$ untranslated region in mammalian mRNAs. Nature Structural \& Molecular Biology 16 144-150.

He L, He X, Lim LP, de Stanchina E, Xuan Z, Liang Y, Xue W, Zender L, Magnus J, Ridzon D et al. 2007 A microRNA component of the p53 tumour suppressor network. Nature 447 1130-1134.

Horwich MD \& Zamore PD 2008 Design and delivery of antisense oligonucleotides to block microRNA function in cultured Drosophila and human cells. Nature Protocols $\mathbf{3}$ 1537-1549.

Hsu RJ, Yang HJ \& Tsai HJ 2009 Labeled microRNA pull-down assay system: an experimental approach for high-throughput identification of microRNA-target mRNAs. Nucleic Acids Research 37 e77.

Hu X, Macdonald DM, Huettner PC, Feng Z, El Naqa IM, Schwarz JK, Mutch DG, Grigsby PW, Powell SN \& Wang X 2009 A miR-200 microRNA cluster as prognostic marker in advanced ovarian cancer. Gynecologic Oncology 114 457-464.

Hutvagner G, Simard MJ, Mello CC \& Zamore PD 2004 Sequence-specific inhibition of small RNA function. PLoS Biology 2 E98.

Iorio MV, Visone R, Di Leva G, Donati V, Petrocca F, Casalini P, Taccioli C, Volinia S, Liu CG, Alder H et al. 2007 MicroRNA signatures in human ovarian cancer. Cancer Research 67 8699-8707.

Jiang Q, Wang Y, Hao Y, Juan L, Teng M, Zhang X, Li M, Wang G \& Liu Y 2009 miR2Disease: a manually curated database for microRNA deregulation in human disease. Nucleic Acids Research 37 D98-104.

John B, Enright AJ, Aravin A, Tuschl T, Sander C \& Marks DS 2004 Human microRNA targets. PLoS Biology 2 e363.

John B, Sander C \& Marks DS 2006 Prediction of human microRNA targets. Methods in Molecular Biology 342 101-113.

Johnson SM, Grosshans H, Shingara J, Byrom M, Jarvis R, Cheng A, Labourier E, Reinert KL, Brown D \& Slack FJ 2005 RAS is regulated by the let-7 microRNA family. Cell 120 635-647. 
Karginov FV, Conaco C, Xuan Z, Schmidt BH, Parker JS, Mandel G \& Hannon GJ 2007 A biochemical approach to identifying microRNA targets. PNAS 104 19291-19296.

Krek A, Grun D, Poy MN, Wolf R, Rosenberg L, Epstein EJ, MacMenamin P, da Piedade I, Gunsalus KC, Stoffel M et al. 2005 Combinatorial microRNA target predictions. Nature Genetics 37 495-500.

Kumar MS, Lu J, Mercer KL, Golub TR \& Jacks T 2007 Impaired microRNA processing enhances cellular transformation and tumorigenesis. Nature Genetics 39 673-677.

Kumar MS, Erkeland SJ, Pester RE, Chen CY, Ebert MS, Sharp PA \& Jacks T 2008 Suppression of non-small cell lung tumor development by the let-7 microRNA family. PNAS 105 3903-3908.

Laios A, O’Toole S, Flavin R, Martin C, Kelly L, Ring M, Finn SP, Barrett C, Loda M, Gleeson N et al. 2008 Potential role of miR-9 and miR-223 in recurrent ovarian cancer. Molecular Cancer 735.

Lawrie CH, Gal S, Dunlop HM, Pushkaran B, Liggins AP, Pulford K, Banham AH, Pezzella F, Boultwood J, Wainscoat JS et al. 2008 Detection of elevated levels of tumour-associated microRNAs in serum of patients with diffuse large B-cell lymphoma. British Journal of Haematology 141 672-675.

Lee RC, Feinbaum RL \& Ambros V 1993 The C. elegans heterochronic gene lin-4 encodes small RNAs with antisense complementarity to lin-14. Cell 75 843-854.

Lewis BP, Shih IH, Jones-Rhoades MW, Bartel DP \& Burge CB 2003 Prediction of mammalian microRNA targets. Cell 115 787-798.

Lim LP, Lau NC, Garrett-Engele P, Grimson A, Schelter JM, Castle J, Bartel DP, Linsley PS \& Johnson JM 2005 Microarray analysis shows that some microRNAs downregulate large numbers of target mRNAs. Nature 433 769-773.

Lodes MJ, Caraballo M, Suciu D, Munro S, Kumar A \& Anderson B 2009 Detection of cancer with serum miRNAs on an oligonucleotide microarray. PLOS ONE 4 e6229.

Lu J, Getz G, Miska EA, Alvarez-Saavedra E, Lamb J, Peck D, Sweet-Cordero A, Ebert BL, Mak RH, Ferrando AA et al. 2005 MicroRNA expression profiles classify human cancers. Nature 435 834-838.

Lu L, Katsaros D, de la Longrais IA, Sochirca O \& Yu H 2007 Hypermethylation of let-7a-3 in epithelial ovarian cancer is associated with low insulin-like growth factor-II expression and favorable prognosis. Cancer Research 67 10117-10122.

Maragkakis M, Reczko M, Simossis VA, Alexiou P, Papadopoulos GL, Dalamagas T, Giannopoulos G, Goumas G, Koukis E, Kourtis K et al. 2009 DIANAmicroT web server: elucidating microRNA functions through target prediction. Nucleic Acids Research 37 W273-W276.
McGuire WP, Hoskins WJ, Brady MF, Kucera PR, Partridge EE, Look KY, Clarke-Pearson DL \& Davidson M 1996 Cyclophosphamide and cisplatin compared with paclitaxel and cisplatin in patients with stage III and stage IV ovarian cancer. New England Journal of Medicine 334 1-6.

Meister G, Landthaler M, Dorsett Y \& Tuschl T 2004 Sequence-specific inhibition of microRNA- and siRNA-induced RNA silencing. RNA 10 544-550.

Mishra PJ \& Merlino G 2009 MicroRNA reexpression as differentiation therapy in cancer. Journal of Clinical Investigation 119 2119-2123.

Nam EJ, Yoon H, Kim SW, Kim H, Kim YT, Kim JH, Kim JW \& Kim S $2008 a$ MicroRNA expression profiles in serous ovarian carcinoma. Clinical Cancer Research 14 2690-2695.

Nam S, Kim B, Shin S \& Lee S $2008 b$ miRGator: an integrated system for functional annotation of microRNAs. Nucleic Acids Research 36 D159-D164.

Orom UA \& Lund AH 2007 Isolation of microRNA targets using biotinylated synthetic microRNAs. Methods $\mathbf{4 3}$ $162-165$.

Ozols RF \& Young RC 1984 Chemotherapy of ovarian cancer. Seminars in Oncology 11 251-263.

Park SM, Shell S, Radjabi AR, Schickel R, Feig C, Boyerinas B, Dinulescu DM, Lengyel E \& Peter ME 2007 Let-7 prevents early cancer progression by suppressing expression of the embryonic gene HMGA2. Cell Cycle 6 2585-2590.

Peter ME 2009 Let-7 and miR-200 microRNAs: guardians against pluripotency and cancer progression. Cell Cycle $\mathbf{8}$ 843-852.

Piver MS, Malfetano J, Baker TR \& Hempling RE 1992 Five-year survival for stage IC or stage I grade 3 epithelial ovarian cancer treated with cisplatin-based chemotherapy. Gynecologic Oncology 46 357-360.

Pratt AJ \& MacRae IJ 2009 The RNA-induced silencing complex: a versatile gene-silencing machine. Journal of Biological Chemistry 284 17897-17901.

Raver-Shapira N, Marciano E, Meiri E, Spector Y, Rosenfeld N, Moskovits N, Bentwich Z \& Oren M 2007 Transcriptional activation of miR-34a contributes to p53-mediated apoptosis. Molecular Cell 26 731-743.

Rehmsmeier M, Steffen P, Hochsmann M \& Giegerich R 2004 Fast and effective prediction of microRNA/target duplexes. RNA 10 1507-1517.

Resnick KE, Alder H, Hagan JP, Richardson DL, Croce CM \& Cohn DE 2009 The detection of differentially expressed microRNAs from the serum of ovarian cancer patients using a novel real-time PCR platform. Gynecologic Oncology 112 55-59.

Roubelakis MG, Zotos P, Papachristoudis G, Michalopoulos I, Pappa KI, Anagnou NP \& Kossida S 2009 Human microRNA target analysis and gene ontology clustering by GOmir, a novel stand-alone application. $B M C$ Bioinformatics 10 (Suppl 6) S20. 
le Sage C, Nagel R, Egan DA, Schrier M, Mesman E, Mangiola A, Anile C, Maira G, Mercatelli N, Ciafre SA et al. 2007 Regulation of the p27(Kip1) tumor suppressor by miR-221 and miR-222 promotes cancer cell proliferation. EMBO Journal 26 3699-3708.

Saito Y, Liang G, Egger G, Friedman JM, Chuang JC, Coetzee GA \& Jones PA 2006 Specific activation of microRNA-127 with downregulation of the protooncogene BCL6 by chromatin-modifying drugs in human cancer cells. Cancer Cell 9 435-443.

Selbach M, Schwanhausser B, Thierfelder N, Fang Z, Khanin R \& Rajewsky N 2008 Widespread changes in protein synthesis induced by microRNAs. Nature 455 58-63.

Sethupathy P, Corda B \& Hatzigeorgiou AG 2006 TarBase: a comprehensive database of experimentally supported animal microRNA targets. RNA 12 192-197.

Shell S, Park SM, Radjabi AR, Schickel R, Kistner EO, Jewell DA, Feig C, Lengyel E \& Peter ME 2007 Let-7 expression defines two differentiation stages of cancer. PNAS 104 11400-11405.

Shen J, Ambrosone CB, DiCioccio RA, Odunsi K, Lele SB \& Zhao H 2008 A functional polymorphism in the miR-146a gene and age of familial breast/ovarian cancer diagnosis. Carcinogenesis 29 1963-1966.

Sorrentino A, Liu CG, Addario A, Peschle C, Scambia G \& Ferlini C 2008 Role of microRNAs in drug-resistant ovarian cancer cells. Gynecologic Oncology 111 478-486.

Tagawa H \& Seto M 2005 A microRNA cluster as a target of genomic amplification in malignant lymphoma. Leukemia 19 2013-2016.

Tarasov V, Jung P, Verdoodt B, Lodygin D, Epanchintsev A, Menssen A, Meister G \& Hermeking H 2007 Differential regulation of microRNAs by $\mathrm{p} 53$ revealed by massively parallel sequencing: miR-34a is a p53 target that induces apoptosis and G1-arrest. Cell Cycle 6 1586-1593.

Taylor DD \& Gercel-Taylor C 2008 MicroRNA signatures of tumor-derived exosomes as diagnostic biomarkers of ovarian cancer. Gynecologic Oncology 110 13-21.

Valastyan S, Reinhardt F, Benaich N, Calogrias D, Szasz AM, Wang ZC, Brock JE, Richardson AL \& Weinberg RA 2009 A pleiotropically acting microRNA, miR-31, inhibits breast cancer metastasis. Cell 137 1032-1046.

Vasudevan S, Tong Y \& Steitz JA 2007 Switching from repression to activation: microRNAs can up-regulate translation. Science 318 1931-1934.

Vatolin S, Navaratne K \& Weil RJ 2006 A novel method to detect functional microRNA targets. Journal of Molecular Biology 358 983-996.

Vinther J, Hedegaard MM, Gardner PP, Andersen JS \& Arctander P 2006 Identification of miRNA targets with stable isotope labeling by amino acids in cell culture. Nucleic Acids Research 34 e107.

Volinia S, Calin GA, Liu CG, Ambs S, Cimmino A, Petrocca F, Visone R, Iorio M, Roldo C, Ferracin M et al. 2006 A microRNA expression signature of human solid tumors defines cancer gene targets. PNAS 103 2257-2261.

Welch C, Chen Y \& Stallings RL 2007 MicroRNA-34a functions as a potential tumor suppressor by inducing apoptosis in neuroblastoma cells. Oncogene $\mathbf{2 6}$ 5017-5022.

Wheeler BM, Heimberg AM, Moy VN, Sperling EA, Holstein TW, Heber S \& Peterson KJ 2009 The deep evolution of metazoan microRNAs. Evolution and Development 11 50-68.

Wright JD, Shah M, Mathew L, Burke WM, Culhane J, Goldman N, Schiff PB \& Herzog TJ 2009 Fertility preservation in young women with epithelial ovarian cancer. Cancer 115 4118-4126.

Wyman SK, Parkin RK, Mitchell PS, Fritz BR, O'Briant K, Godwin AK, Urban N, Drescher CW, Knudsen BS \& Tewari M 2009 Repertoire of microRNAs in epithelial ovarian cancer as determined by next generation sequencing of small RNA cDNA libraries.

PLOS ONE 4 e5311.

Yang H, Kong W, He L, Zhao JJ, O’Donnell JD, Wang J, Wenham RM, Coppola D, Kruk PA, Nicosia SV et al. 2008a MicroRNA expression profiling in human ovarian cancer: miR-214 induces cell survival and cisplatin resistance by targeting PTEN. Cancer Research $\mathbf{6 8}$ 425-433.

Yang N, Kaur S, Volinia S, Greshock J, Lassus H, Hasegawa K, Liang S, Leminen A, Deng S, Smith L et al. $2008 b$ MicroRNA microarray identifies Let-7i as a novel biomarker and therapeutic target in human epithelial ovarian cancer. Cancer Research 68 10307-10314.

Zeng Y \& Cullen BR 2004 Structural requirements for pre-microRNA binding and nuclear export by exportin 5 . Nucleic Acids Research 32 4776-4785.

Zhang L, Huang J, Yang N, Greshock J, Megraw MS, Giannakakis A, Liang S, Naylor TL, Barchetti A, Ward MR et al. 2006 microRNAs exhibit high frequency genomic alterations in human cancer. PNAS $\mathbf{1 0 3}$ 9136-9141.

Zhang W, Dahlberg JE \& Tam W 2007 MicroRNAs in tumorigenesis: a primer. American Journal of Pathology 171 728-738.

Zhang L, Volinia S, Bonome T, Calin GA, Greshock J, Yang N, Liu CG, Giannakakis A, Alexiou P, Hasegawa K et al. 2008 Genomic and epigenetic alterations deregulate microRNA expression in human epithelial ovarian cancer. PNAS 105 7004-7009. 